\title{
ANALISIS RASIO PROFITABILITAS PADA PT. BANK PEMBANGUNAN DAERAH SUMATERA BARAT CABANG UTAMA PADANG
}

\author{
Sintia Pebriyana, Doni Marlius \\ Akademi Keuangan dan Perbankan "Pembangunan" Padang \\ sintiapebriyana02@gmail.com
}

\begin{abstract}
The purpose of this study was to determine the level of health of the West Sumatra Regional Development Bank Padang Main Branch during 2018-2019. The type of data used is secondary data obtained by the documentation method taken from the West Sumatra BPD Main Branch bank publication report during the 2018-2019 period. This research was conducted using 2018-2019 financial statements, namely the balance sheet and income statement. Based on the analysis of profitability based on ROA can be categorized as good, this is based on the results of the calculation of the average return on assets for 2 years there is between $2.17 \%-1.88 \%$. The financial performance of the West Sumatra Regional Development Bank Padang Main Branch during 2018-2019 based on ROE can be categorized as good, this is based on the results of the calculation of the average return on equity for 2 years between $4.5 \%$-4.9\%. The financial performance of BPD Bank Sumatera Barat Main Branch Padang during 2018-2019 based on BOPO can be categorized as good, this is based on the results of 2 years calculation between $77.8 \%$ - 77.6\%. The financial performance of the Bank of West Sumatra Bank BPD Main Branch Padang during 2018-2019 based on NPM can be categorized as good, this is based on the results of the calculation of the average NPM for 2 years between $15.2 \%-16.5 \%$.
\end{abstract}

Keywords: ROA, ROE, BOPO, NPM

PENDAHULUAN

Dalam dunia modern sekarang ini, peranan perbankan dalam memajukan perekonomian suatu negara sangatlah besar. Hampir semua sektor yang berhubungan dengan berbagai kegiatan keuangan selalu membutuhkan jasa bank. Oleh karena itu, perekonomian secara keseluruhan akan memperoleh manfaat dari keberadaan suatu bank. Perekonomian mendapat manfaat berupa mekanisme lokasi sumber-sumber dana secara efektif dan efisien. Industri perbankan memegang peranan penting bagi pembangunan ekonomi sebagai financial intermediary atau perantara pihak yang kelebihan dana dengan pihak yang membutuhkan dana sesuai dengan Undang- Undang Republik Indonesia No. 10 tahun 1998 tentang perbankan bahwa bank adalah badan usaha yang menghimpun dana dari masyarakat dalam bentuk simpanan dan menyalurkannya kepada 
masyarakat dalam bentuk kredit dan atau bentuk-bentuk lainnya dalam rangka meningkatkan taraf hidup rakyat banyak. Kredit merupakan suatu kepercayaan yang diberikan pihak yang kelebihan dana kepada pihak yang kekurangan dana(Marlius, 2018).

Agar dapat melaksanakan tugas pokok dan mempertahankan kelangsungan Bank, kepercayaan masyarakat sangat penting. Untuk memperoleh gambaran tentang perkembangan finansial suatu Bank, perlu mengadakan analisa atau interpretasi terhadap data finansial dari Bank bersangkutan, dimana data finansial tercermin di dalam laporan keuangan yang terdiri dari neraca, laporan laba rugi, laporan arus kas dan lain-lain.

Laporan keuangan merupakan data-data keuangan yang sifatnya kuantitatifyang menggambarkan kondisi keuangan dan hasil usaha suatu perusahaan pada saat tertentu atau jangka waktu tertentu. Dalam menjalankan usahanya sebagai lembaga keuangan kegiatan bank sehari-hari tidak terlepas dari bidang keuntungan. Dalam menganalisa dan menilai posisi keuangan untuk mengetahui seberapa jauh kemampuan bank dalam menghasilkan keuntungan atau laba. Maka untuk mengukur keefektifan kegiatan operasional Bank dapat diketahui melalui rasio profitabilitas. Pengertian rasio profitabilitas adalah rasio yang menunjukan kemampuan perusahaan untuk menghasilkan laba dari kegiatan operasionalnya. Sehingga hasil rasio profitabilitas dapat dijadikan gambaran tentang efektivitas kinerja bank ditinjau dari laba bersih yang diperoleh dibandingkan dengan biaya pendapatannya.

Profitabilitas merupakan faktor yang seharusnya mendapat perhatian penting karena untuk dapat melangsungkan hidupnya, suatu bank harus berada dalam keadaan yangmenguntungkan (profitable). Semakin besar profitabilitas berarti semakin baik, karena kemakmuran bank meningkat dengan semakin besarnya profitabilitas. Rasio profitabilitas terdiri atas Rasio Biaya Operasional (BOPO), Net Profit Margin, Return On Asset dan Return On Equity.

Kinerja keuangan bank dapat diukur dengan kecukupan modal, likuiditas, profitabilitas dan rentabilitas, dan besarnya kredit bermasalah yang dimiliki. Untuk memperoleh gambaran financia lsuatu bank, perlu mengadakan analisa atau interpretasi terhadap data financial dari bank bersangkutan, dimana data financial itu tercermin didalam laporan keuangan. Laporan keuangan merupakan data-data keuangan yang sifatnya kuantitatif.

Untuk memperoleh kinerja kegiatan usaha suatu bank perlu diadakan suatu interpretasi atau analisa terhadap financial bank yang bersangkutan. Analisa yang digunakan adalah dengan menggunakan rasio-rasio keuangan bank sesuai dengan standar yang berlaku. Kinerja yang telah dicapai oleh perusahaan dapat dilihat dari laporan keuangan perusahaan tersebut,manajemen dapat mengetahui posisi keuangan,kinerja keuangan dan kekuatan keuangan melalui analisis rasio laporan keuangan. Analisis rasio laporan keuangan juga diperlukan oleh pihak-pihak yang berkepentingan seperti kreditur, investor, dan pemerintah untuk menilai kondisi keuangan perusahaan dan perkembangan perusahaan tersebut.

Dalam mengukur kinerja keuangan pada perusahaan dengan menggunakan beberapa rasio keuangan. Rasio keuangan dapat dilihat dari rasio likuiditas, solvabilitas, aktivitas, profitabilitas, pertumbuhan, dan penilaian. Setiap rasio 
memiliki kegunaan, tujuan dan makna tersendiri dari masing-masing rasio keuangan. Rasio likuiditas yaitu untuk mengukur kemampuan perusahaan dalam memenuhi kewajiban jangka pendeknya yang telah jatuh tempo. Rasio solvabilitas untuk mengukur seberapa besar perusahaan telah dibiayai oleh hutang. Rasio aktivitas untuk mengukur seberapa efektif perusahaan menggunakan sumber dayanya. Rasio profitabilitas untuk mengukur seberapa efektivitas manajemen perusahaan untuk membuktikan dengan kemampuan menciptakan keuntungan atau menciptakan nilai tambah pada perusahaan. Rasio pertumbuhan merupakan rasio yang menggambarkan kemampuan perusahaan dalam mempertahankan posisi ekonominya pada saat pertumbuhan ekonomi yang terjadi. Rasio penilaian, rasio yang memberikan ukuran kemampuan manajemen dalam menciptakan nilai usahanya di atas biaya investasi. Macam-macam rasio keuangan tersebut sangat bermanfaat bagi perusahaan. Rasio yang digunakan dalam penulisan laporan akhir ini hanya rasio profitabilitas atau rentabilitas. Rasio profitabilitas merupakan rasio yang digunakan untuk menilai kemampuan perusahaan dalam mencari keuntungan dalam suatu periode tertentu. Rasio ini juga memberikan tingkat efektivitas manajemen dalam mengelola perusahan.

Rasio profitabilitas pada perusahaan dapat dikatakan baik apabila mampu memenuhi target laba yang telah ditetapkan berdasarkan aktiva atau modal yang ada pada periode tersebut. Apabila pengelolaan keuangan yang tidak baik akan mengakibatkan terganggunya kinerja perusahaan.Semua pihak yang bersangkutan dalam mengelola keuangan harus mampu melaksanakan tugasnya sebaik mungkin supaya pemasukan dan pengeluaran agar tetap stabil dan perusahaan tidak mengalami kerugian.

Bank Nagari merupakan sebutan untuk PT. Bank Pembangunan Daerah Sumatra Baratatau BPD Sumbar adalah satu-satunya bank milik pemerintah daerah yang berguna untuk meningkatkan perekonomian masyarakat khususnya di sumatera barat. Bank Nagari berpusat di kota padang.

Analisis yang dilakukan pada PT.Bank pembangunan daerah sumatera barat cabang utama padang yaitu analisis rasio profitabilitas, tujuannya untuk mengetahui bagaimana bank mendapatkan laba dan seberapa besar perusahaan ini menggunakan asetnya untuk memperoleh keuntungan.

Tabel 1

Data Keuangan PT.Bank Pembangunan Daerah Sumatera Barat Cabang Utama Padang

Periode Tahun 2018- 2019

( Dalam Rp.000)

\begin{tabular}{|l|r|r|}
\hline Keterangan & $\mathbf{2 0 1 8}$ & \multicolumn{2}{|c|}{$\mathbf{2 0 1 9}$} \\
\hline Total Aset & 23.190 .691 & 24.433 .596 \\
\hline Modal Sendiri & 5.000 .000 & 5.000 .000 \\
\hline Pendapatan Operasional & 1.491 .067 & 1.503 .931 \\
\hline Beban Operasional & 1.160 .599 & 1.167 .482 \\
\hline Laba Sebelum Pajak & 504.818 & 461.504 \\
\hline Laba Setelah Pajak & 227.142 & 249.396 \\
\hline
\end{tabular}

Sumber : Data Keuangan www.banknagari.co.id data diolah 
Berdasarkan tabel 1 dapat dilihat bahwa pada total aset pada tahun 2018 Rp.23.190.691.000, dan tahun 2019 Rp.24.433.596.000 mengalami peningkatan, pada modal sendiri tahun 2018 Rp.5.000.000.000 dan 2019 Rp.5.000.000.000 mengalami peningkatan, pada pendapatan operasional dari 2018 Rp.1.491.067.000 dan tahun 2019 Rp.1.503.931.000 terjadi peningkatan, di beban operasional di 2018 Rp.1.160.599.000 dan 2019 Rp.1.167.482.000 terjadi peningkatan, pada laba sebelum pajak terjadi penurunan dari 2018 Rp.504.818.000 dan tahun 2019 Rp.461.504.000, dan pada laba setelah pajak terjadi peningkatan dari 2018 Rp.227.142.000 dan tahun 2019 Rp.249.396.000.

Dari uraian diatas maka penulis tertarik untuk menganalisis hasil tersebut yang dituangkan dalam bentuk tugas akhir yang berjudul "Analisis Rasio Profitabilitas Pada PT. Bank Pembangunan Daerah Sumatera barat Cabang Utama Padang"

\section{METODE PENELITIAN}

Dalam melakukan penelitian penulis mengunakan mengunakan 2 metode.

1. Metode pengumpulan data.

a. Riset lapangan (Field Research) Yaitu peninjauan lansung keobjek penelitian yang dipilih untuk meneliti hasil data skunder. Adapun cara dengan mewawancarai lansung kepihak-pihak yang berkepentingan dalam hal ini adalah PT. Bank Pembangunan DaerahSumatera Barat Cabang Utama Padang atau instansi yang terkait.

b. Riset Perpustakaan (Library Research) Yaitu penyelidikan yang dilakukan melalui keperpustakaan atau pun buku-buku ilmiah dan tulisan-tulisan yang ada hubungan nya dengan pembahasan yang dilakukan.Penelitian perpustakaan ini bersifat teoritis, dimana dapat diapliklasikan dengan teori-teori yang berhubungan dengan penulisan ini.

2. Metode Analisis Data

Dalam menganalisa data, penulis menggunakan analisa data kuantitatif. Data kuantitatif merupakan data informasi yang berbentuk simbol angka atau bilangan, maka dari itu dengan metode ini penulis akan mencoba memberikan fakta-fakta atau kenyataan yang dialami PT. Bank Pembangunan Daerah Sumatera Barat Cabang Utama Padang.

\section{HASIL DAN PEMBAHASAN}

\section{Analisa Terhadap Return On Asset (ROA)}

Menurut Bank Indonesia (SE BI No. 10/46/DInt. 2008) Return on Asset merupakan rasio yang menggambarkan tingkat keuntungan (earning) yang didapatkan oleh manajemen atas total asset yang dimiliki. Return On Asset adalah rasio yang mencerminkan kesangupan bank dalam mengendalikan dana yang diinvestasikan dalam semua asset yang mendatangkan keuntungan (Kusuma. 2013). Rasio ini dipakai untuk mengukur kesangupan manajemen PT. Bank Pembangunan Daerah Sumatera Barat Cabang Utama Padang dalam mendapatkan keuntungan (laba) secara 
keseluruhan. Rasio ini juga dapat menggambarkan efesiensi kemampuan kerja bank yang bersangkutan dan juga dapat digunakan untuk mengukur kemampuan bank dalam mengelola seluruh biaya-biaya operasional dan nonoperasional. Matriks penilaian tingkat rasio ROA menurut Bank Indonesia adalah sebagai berikut :

Tabel 2

Matriks Kriteria Penilaian Tingkat ROA

\begin{tabular}{|c|c|}
\hline Persentase ROA & Keterangan \\
\hline$>1,5 \%$ & Sangat Baik \\
\hline $1,25 \%-1,5 \%$ & Baik \\
\hline $0,5 \%-1,25 \%$ & Cukup \\
\hline $0 \%-0,5 \%$ & Tidak Baik \\
\hline
\end{tabular}

Sumber : www.bi.go.id

Berdasarkan data yang diperoleh Return On Asset PT. Bank Pembangunan Daerah Sumatera Barat Cabang Utama Padang pada periode 2018 - 2019 ditunjukkan pada tabel dibawah ini :

Tabel 3

Perhitungan Return On Asset PT. Bank Pembangunan Daerah Sumatera Barat Cabang Utama Padang 2018 - 2019

(Dalam Ribuan)

\begin{tabular}{|c|r|r|}
\hline \multirow{2}{*}{ Komponen } & \multicolumn{2}{|c|}{ Return On Asset } \\
\cline { 2 - 4 } & Laba sebelum pajak & \multicolumn{2}{|c|}{ Total Aktiva } \\
\hline 2018 & 504.818 & 23.190 .691 \\
\hline 2019 & 461.504 & 24.433 .596 \\
\hline
\end{tabular}

Sumber : Data Keuangan www.banknagari.co.id data diolah

Dengan Formula :

$$
\mathrm{ROA}=\frac{\text { LAba Sebelum Pajak }}{\text { Total Aktiva }} \times 100 \%
$$

Tahun 2018 :

$$
\mathrm{ROA}=\frac{504.818}{23.190 .691} \times 100 \%=2,17 \%
$$

Tahun 2019:

$$
\mathrm{ROA}=\frac{461.504}{24.318 .596} x 100 \%=1,88 \%
$$

Berdasarkan perhitungan Return On Asset yang telah dilakukan berdasarkan data keuangan Bank Pembangunan Daerah Sumatera Barat Cabang Utama Padang, ROA pada tahun 2018 sebesar 2,17\% dan tahun 2019 sebesar $1,88 \%$. Berdasarkan perhitungan tersebut dapat disimpulkan ROA Bank Pembangunan Daerah Sumatera Barat Cabang Utama Padang masih berfluktuasi. Walaupun demikian perkembagan profitabilitas Bank Pembangunan Daerah Sumatera Barat Cabang Utama Padang dikategorikan sangat baik dan dapat dikatakan efesien. Namun apabila ROA semakin rendah 
bank tidak akan bisa beroperasi dengan efektif dan efesien dalam memanfaatkan asset yang dimiliki oleh bank untuk menghasilkan keuntungan.

2. Analisa Terhadap Return On Equity (ROE)

Menurut (SE BI No. 10/46/DInt. 2008) Return On Equity (ROE) merupakan rasio yang menyatakan tingkat pengembalian (return) yang didapatkan oleh manajemen atas modal yang ditanam oleh pemegang saham. Return On Equity (ROE) merupakan rasio yang dipakai untuk mengukur kemampuan manajemen bank dalam memanfaaatkan modal yang tersedia (ekuitas) untuk mendatangkan laba setelah pajak (Kusuma. 2013). Rasio ini menerangkan daya untuk mendapatkan laba atas investasi berdasarkan nilai buku para pemegang saham. Semakin tinggi rasio ini, semakin baik, demikian pula sebaliknya. ROE yang tinggi akan dapat mendorong penerimaan bank atas peluang investasi yang baik dan manajemen biaya yang efektif. Hal ini dapat mempengaruhi minat investor untuk melakukan transaksi jual beli saham, sehingga akan meningkatkan volume penjualan saham perusahaan tersebut.

Matriks penilaian tingkat rasio ROE menurut Bank Indonesia adalah sebagai berikut (Surat Edaran BI No. 13/24/DPNP 2011) :

Tabel 4

Matriks Kriteria Penilaian Tingkat ROE

\begin{tabular}{|c|c|}
\hline Persentase ROE & Keterangan \\
\hline$>23 \%$ & Sangat Baik \\
\hline $18 \%-23 \%$ & Baik \\
\hline $13 \%-18 \%$ & Cukup \\
\hline $8 \%-13 \%$ & Tidak Baik \\
\hline$<8 \%$ & Sangat Tidak Baik \\
\hline
\end{tabular}

Sumber : www.bi.go.id

Berdasarkan data yang diperoleh Return On Equity PT. Bank

Pembangunan Daerah Sumatera Barat Cabang Utama Padang pada periode 2018 - 2019 ditunjukkan pada tabel dibawah ini.

Tabel 5

Perhitungan Return On Equity PT. Bank Pembangunan Daerah Sumatera Barat Cabang Utama Padang 2018 - 2019

(Dalam Ribuan)

\begin{tabular}{|c|r|r|}
\hline \multirow{2}{*}{ Komponen } & \multicolumn{2}{|c|}{ Return On Equity } \\
\cline { 2 - 3 } & Laba setelah pajak & \multicolumn{2}{|c|}{ Modal Sendiri } \\
\hline 2018 & 227.142 & 5.000 .000 \\
\hline 2019 & 249.396 & 5.000 .000 \\
\hline
\end{tabular}

Sumber : Data Keuangan www.banknagari.co.id data diolah 
Dengan Formula :

$$
\mathrm{ROE}=\frac{\text { LAba Setelah Pajak }}{\text { Modal Sendiri }} \times 100 \%
$$

Tahun 2018 :

$$
\mathrm{ROE}=\frac{227.142}{5.000 .000} \times 100 \%=4,5 \%
$$

Tahun 2019 :

$$
\mathrm{ROE}=\frac{249.396}{5.000 .000} \times 100 \%=4,9 \%
$$

Berdasarkan perhitungan Return On Equity yang telah dilakukan, berdasarkan data keuangan Bank Pembangunan Daerah Sumatera Barat Cabang Utama Padang, ROE Bank Pembangunan Daerah Sumatera Barat Cabang Utama Padang tahun 2018 sebesar 4,5\% dan tahun 2019 sebesar 4,9\%. Berdasarkan perhitungan tersebut ROE Bank Pembangunan Daerah Sumatera Barat Cabang Utama Padang bila dibandingkan pada tahun 2019 Return On Equity mengalami peningkatkan sebesar 0,4\%. Walaupun dengan persentase yang cukup rendah pada tahun 2018, bank masih cukup efektif dan efesien dalam memanfaatkan modal yang dimilikinya untuk memperoleh keuntungan.

3. Analisa Beban Operasional Terhadap Pendapatan Operasional

Rasio beban operasional diguanakan untuk mengukur ringkat efisiensi dan kemampuan bank dalam melakukan kegiatan operasionalnya. Rasio BOPO sering disebut rasio efisiensi digunakan untuk mengukur kemampuan manajemen bank dalam mengendalikan biaya operasional terhadap pendapatan operasional.

Matriks penilaian tingkat rasio BOPO menurut Bank Indonesia adalah sebagai berikut (Surat Edaran BI No. 13/24/DPNP 2011) :

Tabel 6

Matriks Kriteria Penilaian Tingkat BOPO

\begin{tabular}{|c|c|}
\hline Persentase BOPO & Keterangan \\
\hline$<83 \%$ & Sangat Baik \\
\hline $83 \%-85 \%$ & Baik \\
\hline $85 \%-87 \%$ & Cukup \\
\hline $87 \%-89 \%$ & Tidak Baik \\
\hline$>89 \%$ & Sangat Tidak Baik \\
\hline
\end{tabular}

Sumber : www.bi.go.id

Berdasarkan data yang diperoleh Beban Operasional terhadap Pendapatan Operasional Bank (BOPO) PT. Bank Pembangunan Daerah Sumatera Barat Cabang Utama Padang pada periode 2018 - 2019 ditunjukkan pada tabel dibawah ini : 
Tabel 7

Perhitungan Biaya Operasional Terhadap Pendapatan Operasional PT. Bank Pembangunan Daerah Sumatera Barat Cabang Utama Padang $2018-2019$

\begin{tabular}{|c|c|c|}
\multicolumn{2}{|c|}{ (Dalam Ribuan) } \\
\hline \multirow{2}{*}{ Komponen } & \multicolumn{2}{|c|}{ B O P O } \\
\cline { 2 - 4 } & Total pendapatan Operasional & Total Beban Operasional \\
\hline 2018 & 1.491 .067 & 1.160 .599 \\
\hline 2019 & 1.503 .931 & 1.167 .482 \\
\hline
\end{tabular}

Sumber : Data Keuangan www.banknagari.co.id data diolah

Dengan Formula :

$$
\mathrm{ROE}=\frac{\text { Total Biaya Operasional }}{\text { Total Pendapaatan Operasional }} \times 100 \%
$$

Tahun 2018 :

$$
\mathrm{BOPO}=\frac{1.160 .599}{1.491 .067} \times 100 \%=77,8 \%
$$

Tahun 2019 :

$$
\mathrm{BOPO}=\frac{1.167 .482}{1.503 .931} \times 100 \%=77,6 \%
$$

Berdasarkan perhitungan Biaya Operasional Terhadap Pendapatan Operasional yang telah dilakukan, berdasarkan data keuangan Bank Pembangunan Daerah Sumatera Barat Cabang Utama Padang, BOPO Bank Pembangunan Daerah Sumatera Barat Cabang Utama Padang tahun 2018 sebesar 77,8\% dan tahun 2019 sebesar 77,6\%. Dari hasil tersebut pada tahun 2019 kineja keuangan Bank Pembangunan Daerah Sumatera Barat Cabang Utama Padang dapat dikatakan sangat baik, bila dibandingkan dengan tahun 2018 yang belum cukup efesien, walaupun demikian persentase BOPO masih tergolong kedalam rata-rata penilaian BI. Semakin kecil BOPO semakin efesien bank tersebut dalam mengendalikan biaya operasionalnya, maka keuntungan yang diperoleh bank akan maksimal.

4. Analisa Terhadap Net Profit Margin (NPM)

Net Profit Margin adalah rasio profitabilitas yang digunakan untuk mengukur persentase laba bersih pada suatu perusahaan terhadap penjualan bersihnya. Margrin Laba Bersih ini menunjukan proporsi penjualan yang tersisa setelah dikurangi semua biaya terkait. Net Profit Margin ini sering disebut juga dengan Profit Margin Ratio (Rasio Marjin Laba).

Menurut Bank Indonesia (SE BI No. 10/46/DInt. 2008) Net Profit Margin merupakan rasio yang memperlihatkan kontribusi penjualan terhadap laba bersih yang dihasilkan. Rasio ini mengukur sejauh mana kemampuan bank BNI Syariah dalam mendatangkan laba bersih pada tingkat penjualan/ pendapatan tertentu. Rasio ini bisa diinterprestasikan juga sebagai kemampuan bank menekan biayabiaya perusahaan pada periode tertentu. Matriks penilaian tingkat rasio NPM menurut Bank Indonesia adalah sebagai berikut (Surat Edaran BI No. 6/23/DPNP 2004) : 
Tabel 8

Matriks Kriteria Penilaian Tingkat NPM

\begin{tabular}{|c|c|}
\hline Persentase NPM & Keterangan \\
\hline$>100 \%$ & Sangat Baik \\
\hline $81 \%-100 \%$ & Baik \\
\hline $66 \%-100 \%$ & Cukup \\
\hline $51 \%-66 \%$ & Tidak Baik \\
\hline$<51 \%$ & Sangat Tidak Baik \\
\hline
\end{tabular}

Sumber : www.bi.go.id

Berdasarkan data yang diperoleh Net Profit Margin Bank Pembangunan Daerah Sumatera Barat Cabang Utama Padang pada periode 2018 - 2019 ditunjukkan pada tabel dibawah ini.

\section{Tabel 9}

Perhitungan Net Profit Margin

\section{PT. Bank Pembangunan Daerah Sumatera Barat Cabang Utama Padang} $2018-2019$

\begin{tabular}{|c|r|r|}
\multicolumn{2}{|c|}{ (Dalam Ribuan) } \\
\hline \multirow{2}{*}{ Komponen } & \multicolumn{2}{|c|}{ Net Profit Margin } \\
\cline { 2 - 3 } & Laba Setelah Pajak & Total Pendapatan Operasional \\
\hline 2018 & 227.142 & 1.491 .067 \\
\hline 2019 & 249.396 & 1.503 .931 \\
\hline
\end{tabular}

Sumber : Data Keuangan www.banknagari.co.id data diolah

Dengan Formula :

$$
\mathrm{NPM}=\frac{\text { Laba Setelah Pajak }}{\text { Total Pendapaatan Operasional }} \times 100 \%
$$

Tahun 2018 :

$$
\mathrm{NPM}=\frac{227.142}{1.491 .067} x 100 \%=15,2 \%
$$

Tahun 2019 :

$$
\mathrm{NPM}=\frac{249.396}{1.503 .931} x 100 \%=16,5 \%
$$

Berdasarkan perhitungan Net Profit Margin yang telah dilakukan, berdasarkan data keuangan Bank Pembangunan Daerah Sumatera Barat Cabang Utama Padang, NPM Bank Pembangunan Daerah Sumatera Barat Cabang Utama Padang tahun 2018 sebessar 15,2\% dan tahun 2019 sebesar 16,5\%. Berdasarkan perhitungan tersebut NPM Bank Pembangunan Daerah Sumatera Barat Cabang Utama Padang bila dibandingkan pada tahun 2019 mengalami kenaikan, berarti kemampuan bank dalam memperoleh laba dengan pengelolaan biaya operasional bank juga semakin efektif. Jika rasio ini semakin besar maka akan semakin baik. 


\section{PEMBAHASAN}

Perbandingan Rasio-Rasio Profitabilitas

Tingkat profitabilitas adalah tingkat kemampuan perusahaan untuk mendapatkan laba dari setiap pengelolaan yang dimiliki untuk mengetahui kondisi profitabilitas yang diperoleh perusahaan, hal itu bisa diketahui dengan menggunakan rasio profitabilitas. Hasil dari analisis rasio tersebut akan menggambarkan kondisi kinerja keuangan perusahaan selama periode tertentu.

Setelah dihitung dengan menggunakan 4 rasio profitabilitas, yaitu dengan menggunakan rasio Return On Assets, Return On Equity, BOPO dan Net Profit Margin, maka dapat dilihat dan dibandingkan hasil perhitungan rasio profitabilitas Bank Pembangunan Daerah Sumatera Barat Cabang Utama Padang selama tahun 2018- 2019 dari tabel berikut:

\section{Tabel 10 \\ Hasil Perbandingan Rasio Profitabilitas \\ PT. Bank Pembangunan Daerah Sumatera Barat Cabang Utama Padang} $2018-2019$

\begin{tabular}{|l|c|c|}
\hline \multirow{2}{*}{ Profitabilitas } & \multicolumn{2}{|c|}{ Tahun } \\
\cline { 2 - 3 } & 2018 & 2019 \\
\hline ROA & $2,17 \%$ & $1,88 \%$ \\
\hline ROE & $4,5 \%$ & $4,9 \%$ \\
\hline BOPO & $77,8 \%$ & $77,6 \%$ \\
\hline NPM & $15,2 \%$ & $16,5 \%$ \\
\hline
\end{tabular}

Sumber : Data Olah

Dari data tersebut dapat dilihat bahwa perbandingan rasio- rasio profitabilitas tersebut memiliki hasil yang hampir sama, yaitu cenderung mengalami kenaikan setiap tahunnya. Selain itu, hasil perhitungan rasio- rasio tersebut juga berada dalam penilian BI. Hal ini menunjukkan bahwa Bank Pembangunan Daerah Sumatera Barat Cabang Utama Padang cukup mampu mengelola keuangannya secara efektif dan hal ini juga menunjukkan bahwa kinerja keuangan Bank Pembangunan Daerah Sumatera Barat Cabang Utama Padang berdasarkan rasio- rasio profitabilitas dapat dikategorikan baik.

\section{SIMPULAN}

1. Berdasarkan hasil analisis pada bab sebelumnya dapat ditarik kesimpulan sebagai berikut: Kinerja keuangan Bank Pembangunan Daerah Sumatera Barat Cabang Utama Padang selama tahun 2018 - 2019 berdasarkan ROA dapat dikategorikan baik, hal ini berdasarkan hasil perhitungan rata-rata return on asset selama 2 tahun barada diatas 2,17\%-1,88\%.

2. Kinerja keuangan Bank Pembangunan Daerah Sumatera Barat Cabang Utama Padang selama tahun 2018 - 2019 berdasarkan ROE dapat dikategorikan baik, hal ini berdasarkan hasil perhitungan rata-rata return on equity selama 2 tahun barada antara $4,5 \%-4,9 \%$.

3. Kinerja keuangan Bank Pembangunan Daerah Sumatera Barat Cabang Utama Padang selama tahun 2018- 2019 berdasarkan BOPO dapat dikategorikan baik, hal ini berdasarkan hasil perhitungan rata-rata BOPO selama 2 tahun barada berada antara $77,8 \%-77,6 \%$. 
4. Kinerja keuangan Bank Pembangunan Daerah Sumatera Barat Cabang Utama Padang selama tahun 2018- 2019 berdasarkan NPM dapat dikategorikan baik, hal ini berdasarkan hasil perhitungan rata-rata NPM selama 2 tahun barada antara $15,2 \%-16,5 \%$.

\section{DAFTAR PUSAKA}

Anggreni, M. R., \& Suardhika, M. S. (2014). Pengaruh Dana Pihak Ketiga, Kecukupan Modal, Risiko Kredit Dan Suku Bunga Kredit Terhadap Profitabilitas Bank Bumn Tahun 2010-2012. E-Jurnal Akuntansi, 9(1), 2737.

Badria, M., \& Marlius, D. (2019). Analisis Rasio Likuiditas Pada PT. Bank Perkreditan Rakyat (BPR) Lengayang. https://doi.org/10.31219/osf.io/esvb7

Djahidin, F. (2008). analisa laporan keuangan. In Saadiah (Ed.), analisa laporan keuangan (kedua, Vol. 5, Issue 1, p. 175). Balai Aksara.

Fitri, H. Y., \& Marlius, D. (2019). Analisis Rasio Likuiditas Pada PT. Bank Perkreditan Rakyat (BPR) Nagari Kasang. https://doi.org/10.31219/osf.io/bcs73

Marlius, D. (2018). Pengendalian Kredit Dalam Upaya Menciptakan Bank Yang Sehat Pada BPR. Bank Pembangunan Daerah Sumatera Barat Cabang Utama Padang. Akademi Keuangan Dan Perbankan Padang, 2007, 1-11.

Munawir. (2012). Perbandingan Kinerja Keuangan Bank Mandiri, Bri Dan Bni Yang Terdaftar Di Bursa Efek Indonesia. Jurnal EMBA ISSN 2303-1174, 1(3), 782-792.

Mustika, S., \& Marlius, D. (2019). Analisa Tingkat Kesehatan Keuangan PT. Bank Perkreditan Rakyat (BPR) Batang Palangki. https://doi.org/10.31219/osf.io/wupyh

Prakosa, K. B. (2004). Analisis Pengaruh Dana Alokasi Umum (DAU) Terhadap Prediksi Belanja Daerah. JAAI, 8(2), 101-118.

Prasajaya, A. . Y. (2013). Amelia Showalter_SearchLove London 2013. E- Jurnal Akuntansi Universitas Udayana 4.1 (2013) 230-245, 1, 230-245. https://doi.org/10.1016/j.jemermed.2010.11.035

Purwanto, A. J. (2014). Pentingnya Mempelajari Teori Organisasi. Teori Organisasi, 1-51.

Saraswati, R. A. (2012). Peranan Analisis Laporan Keuangan, Penilaian Prisip 5C Calon Debitur Dan Pengawasan Kredit Terhadap Efektivitas Pemberian Kredit Pada BPR Bank Pasar Kab Temanggung. Jurnal Nominal, I(5), 1-13.

Sari, Y. P., \& Marlius, D. (2019). Analisis Rasio Profitabilitas Pada PT. Bank Negara Indonesia Syariah. https://doi.org/10.31219/osf.io/94bwq

Subramanyam, K. . (2010). Analisa Laporan Keuangan. In tim salemba Empat (Ed.), Analisa Laporan Keuangan (Edisi Ke10, pp. 1-345). Salemba Empat.

Undang-undang nomor 10 tahun. (1998). Nomor 10 Tahun 1998 Perubahan Atas Undang-undang Nomor 7 Tahun 1992 (Issue 3). 